\title{
Effect of Two Different Biochars as a Component of Compound Feed on Nutrient Digestibility and Performance Parameters in Growing Pigs
}

\section{OPEN ACCESS}

Edited by:

Anna Katharine Shoveller, University of Guelph, Canada

Reviewed by:

David Solà-Oriol,

Autonomous University of Barcelona, Spain Brian Kerr,

Agricultural Research Service (USDA),

United States

*Correspondence: Dana Carina Schubert dana.carina.schubert@ tiho-hannover.de

Specialty section:

This article was submitted to

Animal Nutrition,

a section of the journal

Frontiers in Animal Science

Received: 26 November 2020

Accepted: 18 January 2021

Published: 09 February 2021

Citation:

Schubert DC, Chuppava B, Witte F

Terjung $N$ and Visscher $C$ (2021)

Effect of Two Different Biochars as a

Component of Compound Feed on

Nutrient Digestibility and Performance

Parameters in Growing Pigs.

Front. Anim. Sci. 2:633958.

doi: 10.3389/fanim.2021.633958

\section{Dana Carina Schubert ${ }^{1 *}$, Bussarakam Chuppava ${ }^{1}$, Franziska Witte ${ }^{2}$, Nino Terjung ${ }^{2}$ and Christian Visscher ${ }^{1}$}

${ }^{1}$ Institute for Animal Nutrition, University of Veterinary Medicine, Hanover, Germany, ${ }^{2}$ Department for Product Innovation, German Institute for Food Technologies (DIL e.V.), Quakenbrück, Germany

The objective of this study was to examine two different biochars as a component of compound feed regarding their effects on nutrient digestibility and performance parameters in growing pigs. A total of 18 male, intact piglets $(N=18)$ with 26 days of age and an initial bodyweight of $6.88 \mathrm{~kg}$ were divided into three homogeneous groups of six animals each $(n=6)$. Treatments were control (CON, no addition of biochar), $2 \%$ biochar 1 (BC 1, diet containing 2\% biochar 1), and 2\% biochar 2 (BC 2, diet containing $2 \%$ biochar 2). Before the start of the trials, the biochars were characterized regarding Brunnauer-Emmet-Teller (BET) surface area, surface energy, humidity, and ash content. During the first trial (weeks 1-6) a $3 \times 3$ Latin square was used to determine the apparent total tract digestibility (ATTD) of all three feed in each animal $(N=54, n=18)$. By start of the second trial on day 42, three new homogenous groups were formed with two animals from each of the previous groups. Each group received one of the three diets for 4 weeks. In the first trial, the ATTD of dry matter, organic matter, ether extract, crude fiber, and $\mathrm{N}$-free extract was higher $(p<0.05)$ in pigs fed the biochar diets $(\mathrm{BC} 1$ and $\mathrm{BC} 2)$ than in those animals fed the control diet. The greatest difference was found for ATTD of crude fiber, which was increased by 19.8 and $23.8 \%$, respectively (CON: $30.8^{\mathrm{b}}$ $\pm 13.4 \%$; BC 1: $38.4^{\mathrm{a}} \pm 8.2 \%$; BC 2: $40.4^{\mathrm{a}} \pm 12.2 \%$ ). ATTD of crude protein was only higher in BC 2 compared to CON (CON: $81.0^{\mathrm{b}} \pm 4.1 \%$; BC 1: $82.4^{\mathrm{ab}} \pm 3.6 \%$; BC 2: $\left.84.2^{\mathrm{a}} \pm 3.4 \%\right)$. In both trials, the different treatments revealed no effects on $\mathrm{ADFI}, \mathrm{ADWG}$ or G:F ( $p>0.05)$. The results indicate that no negative effects can be expected when $2 \%$ biochar is included in the feed for growing pigs.

Keywords: biochar, nutrient digestibility, piglet, performance parameter, feed efficiency

\section{INTRODUCTION}

In order to withstand economic pressure, modern livestock farming must become increasingly efficient (De Clercq et al., 2018; Isermeyer, 2020). Simultaneously, society as well as politics demand a change toward sustainable agriculture (Darnhofer et al., 2016; Franková and Cattaneo, 2018). These problems are a burden not only on agriculture in general but also on pork production in 
particular. Adding biochar to the complete feed for pigs could be beneficial for various reasons such as improvement of animal health, binding of feed contaminants (Schmidt et al., 2019) and reduction in greenhouse gases by applying the manure containing the biochar to the soil (Lehmann et al., 2006; Fowles, 2007). Biochar is a carbon-rich material produced by pyrolysis of biomass at temperatures between 350 and $1000^{\circ} \mathrm{C}$ at lowoxygen levels (EBC, 2012). In Germany, the use of biochar in animal feed is permitted by the European Union (EU) Regulation No. 68/2013 (European Commission, 2013), which lists "vegetal carbon; [charcoal]" as feed material. In general, different kind of (trunk) woods as well as other organic materials like rootstocks, harvest leftovers, cotton fibers, and fermentation residues from biogas plants can serve as such biomass (EBC, 2012; Chia et al., 2015). The biochars used in this study were made of beech, larch, spruce and oak (biochar 1) and oak (biochar 2). Taking into account that processing pressure, heating rate, and residence time at peak temperature are further variables in the course of biochar production, the variety of biochars is enormous (Lehmann et al., 2011; Ameloot et al., 2013; Wang et al., 2015; Xie et al., 2015). Owing to the fact that properties of biochar seem to play an important role in relation to their effects in animals and on in vitro fermentation, respectively (Leng et al., 2013; Mcfarlane et al., 2017), it is advisable to characterize biochars in order to allow comparisons to be made between different studies. In general, biochar has an immense internal surface area due to its extremely porous structure, enabling biochar to absorb gases, inorganic nutrients, and soluble organic matter (Thies and Rillig, 2009). The porous structure can also serve as a habitat for bacteria and other microbes (Pietikäinen et al., 2000; Thies and Rillig, 2009). Furthermore, biochar influences the microbial activity by serving as an electron mediator (Chen et al., 2014; Kappler et al., 2014; Sun et al., 2017), and can also alter the microbial composition (Teoh et al., 2019; Terry et al., 2019).

Biochar has been shown to increase the digestibility of feedstuff (Kim et al., 2017; Saleem et al., 2018). Kim et al. (2017) found, using an in vitro design simulating the ileal environment of pigs, an improvement in the digestibility of dry matter (DM) and organic matter $(\mathrm{OM})$ when adding $0.25 \%$ organic medical charcoal to pig feed. In the same study, the addition of either $0.5 \%$ pyroligneous charcoal or $0.5 \%$ coconut tree charcoal did not lead to increased digestibility. The effect of charcoal on the digestibility of other nutrients is not mentioned in the study by Kim et al. (2017). Adding biochar up to $2 \%$ to in vitro rumen fermentation vessels increased the disappearance of DM (74.9 vs. $73.2 \%$ ), OM (74.9 vs. $72.9 \%$ ), crude protein (CP, 86.2 vs. $84.3 \%$ ), acid detergent fiber (ADF, 36.8 vs. $29.9 \%$ ), and neutral detergent fiber (NDF, 44.8 vs. $39.9 \%$ ) compared to a control with no biochar, respectively (Saleem et al., 2018). An increase in the digestibility of DM, OM, and CP but not of NDF and ADF in

\footnotetext{
Abbreviations: ADFI, average daily feed intake; ADWG, average daily weight gain; ATTD, apparent total tract digestibility; BC 1 , feed containing $2 \%$ biochar 1 ; BC 2 , feed containing 2\% biochar 2; BVL, Federal Office of Consumer Protection and Food Safety; BW, body weight; CON, control feed; DM, dry matter; EE, ether extract; FC, feeding cycle; G:F, feed efficiency; FP, fattening period; NfE, nitrogenfree extract; OM, organic matter; SD, standard deviation; $\mathrm{CF}$, crude fiber; $\mathrm{CP}$, crude protein.
}

vivo due to adding bamboo charcoal to a diet based on foliage from Acacia mangium and Para grass was reported in growing goats (Van et al., 2006). In terms of performance parameters, studies report higher growth rates and improved feed conversion rates that occurred either alone or both together in pigs (Chu et al., 2013b; Sivilai et al., 2018) and poultry (Kutlu et al., 2001; Majewska et al., 2002, 2009; Kana et al., 2011) as well as in ruminants (Van et al., 2006; Leng et al., 2012). Chu et al. (2013b) assume that the improved feed efficiency that they observed in pigs is a consequence of an increased villus height due to biochar (Mekbungwan et al., 2004; Ruttanavut et al., 2009). Nevertheless, not all studies with charcoal resulted in positive effects on nutrient digestibility or performance parameters (Pereira et al., 2014; Hinz et al., 2019). In cows that received good quality silage, no improvement in digestibility and milk yield could be shown by the addition of 20 and $40 \mathrm{~g} / \mathrm{d}$ activated carbon. On the contrary, the study showed a reduced feeding preference with increasing carbon content of the feed (Erickson et al., 2011).

There are only very few studies focusing on the effects of biochar in pigs and on their performance parameters. In fact, to the best of the authors' knowledge, to date, no study has been conducted to examine the effect of biochar on nutrient digestibility in pigs. The potential of biochar to have positive effects on animals is undeniable, but given the contradictory results of some studies, the aim of the present study was to examine the effects of two different biochars on nutrient digestibility and performance parameters in growing pigs.

\section{MATERIALS AND METHODS \\ Characterization of Biochars}

The biochars used in this study were both made of wood-based feedstock. For biochar 1 a mixture of beech, larch, spruce and oak was used, while biochar 2 was produced only from oak. The surface energy was determined in accordance with the model of Owens, Wendt, Rabel, and Kaelble [Owens and Wendt, 1969]. This model is based on the measurement of the contact angle between different liquids and the surface of the biochars. The liquids used were water, formamide, ethanol, diiodomethane, and $n$-hexane. Chemical elements were analyzed by means of energy-dispersive-X-ray spectroscopy (EDX). Humidity and $\mathrm{pH}$ were determined in accordance with the official compilation of test methods by BVL (Renger and Stachel, 2010). Except for the determination of BET surface area that was carried out in an external laboratory (ZetA Partikelanalytik GmbH, Mainz, Germany), the analyses of the biochars were performed in the German Institute for Food Technologies (DIL e.V., Quakenbrück, Germany). The results are shown in Table 1.

\section{Ethical Statement}

Animal experiments were carried out in accordance with German regulations and were approved by the Ethics Committee of Lower Saxony for the Care and Use of Laboratory Animals (LAVES: Niedersächsisches Landesamt für Verbraucherschutz und Lebensmittelsicherheit; reference: 33.8-42502-05-18A334). 
TABLE 1 | Chemical and physical characteristics of biochar 1 and biochar 2.

\begin{tabular}{lcc}
\hline Item & Biochar $\mathbf{1}$ & Biochar $\mathbf{2}$ \\
\hline Surface energy total $[\mathrm{mN} / \mathrm{m}]$ & 26.3 & 22.5 \\
$\quad$ Disperse & 12.1 & 15.6 \\
Polar & 14.2 & 6.80 \\
BET $\left[\mathrm{m}^{2} / \mathrm{g}\right]$ & 503 & 174 \\
Chemical elements [\%] & & \\
$\quad$ Carbon & 83.0 & 85.1 \\
Oxygen & 10.9 & 12.6 \\
Calcium & 1.85 & 1.48 \\
Potassium & 2.87 & 0.56 \\
Magnesium & 0.33 & 0.12 \\
$\quad$ Sulfur & 0.30 & 0.02 \\
Humidity [\%] & 22.3 & 5.88 \\
pH & 10.3 & 9.87 \\
\hline
\end{tabular}

TABLE 2 | Composition [\%] of the basis feed for the experimental diets.

\begin{tabular}{lcc}
\hline Item & Control & BC-test \\
\hline Barley & 35.0 & 35.7 \\
Wheat & 16.0 & 20.8 \\
Soybean meal ${ }^{*}$ & 15.0 & 17.0 \\
Maize & 15.0 & 9.2 \\
Waffle meal & 4.0 & 4.1 \\
Wheat bran & 4.0 & 2.0 \\
Beet pulp & 1.0 & 1.1 \\
Sunflower extraction meal & 1.0 & 1.1 \\
Fish protein concentrate & 1.0 & 1.1 \\
Premix & 8.0 & 7.9 \\
\hline
\end{tabular}

*Soybean meal made from genetically modified soybeans. ${ }^{* *}$ Contains fats and oils; additives (per kg feed); nutritional additives: variant 1: vitamin A (10,000 IU), vitamin D/vitamin D3 (1675 IU), vitamin E (80 mg), iron from iron-(II)-sulfate monohydrate (104 mg), copper from copper-(II)-sulfate pentahydrate $(8 \mathrm{mg})$, copper from copper chelate of the hydroxyl analog of methionine (4 mg), manganese from manganese-(II)-sulfate (46 mg), manganese from manganese chelate of the hydroxyl analog of methionine $(8 \mathrm{mg})$, zinc from zinc sulfate monohydrate $(67 \mathrm{mg})$, zinc from zinc chelate of the hydroxyl analog of methionine $(17 \mathrm{mg})$, iodine from calcium iodate anhydrous $(1.7 \mathrm{mg})$, selenium from sodium selenite $(0.21 \mathrm{mg})$, selenium methionine from Saccheromyces cerevisiae $(0.08 \mathrm{mg})$; variant 2: vitamin $A(10,200 \mathrm{IU})$, vitamin D/vitamin D3 (1700 IU), vitamin $E(81 \mathrm{mg})$, iron from iron(II)-sulfate monohydrate (106 mg), copper from copper-(II)-sulfate pentahydrate $(9 \mathrm{mg})$, copper from copper chelate of the hydroxyl analog of methionine $(4 \mathrm{mg})$, manganese from manganese-(II)-sulfate (47 mg), manganese from manganese chelate of the hydroxyl analog of methionine $(9 \mathrm{mg})$, zinc from zinc sulfate monohydrate $(68 \mathrm{mg})$, zinc from zinc chelate of the hydroxyl analog of methionine $(17 \mathrm{mg})$, iodine from calcium iodate anhydrous $(1.7 \mathrm{mg})$, selenium from sodium selenite $(0.21 \mathrm{mg})$, selenium methionine from Saccheromyces cerevisiae $(0.08 \mathrm{mg})$.

\section{Animals and Housing}

The study was carried out with 18 male, intact, mixed breed pigs (dam line: db.victoria, sire line: db.77 of BHZP genetic) with 26 days of age and an initial body weight (BW) of 6.88 $\pm 1.17 \mathrm{~kg}$. The pigs came from the Farm for Education and Research in Ruthe, University of Veterinary Medicine Hannover, Foundation, Germany. The pigs were housed individually in $3 \times 1 \mathrm{~m}$ boxes (reduced to $2 \times 1 \mathrm{~m}$ during fecal collection) equipped with an infrared warming lamp and a $1 \mathrm{~m}^{2}$ rubber mat
TABLE 3 | Energy content and chemical composition of the experimental diets.

\begin{tabular}{|c|c|c|c|c|}
\hline Item & & Control feed & $2 \%$ biochar 1 & $2 \%$ biochar 2 \\
\hline $\begin{array}{l}\text { Metabolizable } \\
\text { energy (ME) }\end{array}$ & MJ per kg diet & 13.55 & 13.52 & 13.59 \\
\hline $\begin{array}{l}\text { Organic } \\
\text { matter }\end{array}$ & $\%$ DM & 94.7 & 94.9 & 94.8 \\
\hline Crude protein & & 19.4 & 18.0 & 17.7 \\
\hline Lysine & & 1.42 & 1.28 & 1.28 \\
\hline Ether extract & & 4.29 & 4.11 & 4.13 \\
\hline Crude fiber & & 4.65 & 4.55 & 4.37 \\
\hline $\begin{array}{l}\text { Nitrogen-free } \\
\text { extract (NfE) }\end{array}$ & & 66.4 & 68.2 & 68.6 \\
\hline Calcium & & 0.792 & 0.777 & 0.806 \\
\hline Phosphorus & & 0.586 & 0.547 & 0.542 \\
\hline Potassium & & 0.806 & 0.701 & 0.697 \\
\hline Magnesium & & 0.233 & 0.199 & 0.198 \\
\hline Sodium & & 0.221 & 0.284 & 0.227 \\
\hline Iron & ppm DM & 366 & 402 & 366 \\
\hline Copper & & 28.9 & 25.5 & 24.3 \\
\hline Zinc & & 151 & 152 & 155 \\
\hline Selenium & & 0.553 & 0.671 & 0.619 \\
\hline
\end{tabular}

${ }^{a}$ Metabolizable Energy (ME) calculated from the specified raw nutrient content. ${ }^{b}$ Nitrogen-free extract $(\mathrm{NfE})=$ dry matter $-($ ash + crude protein + ether extract + crude fiber).

as lying area until day 14 of the trial. Access to water and feed was provided by a nipple drinker and a $1 \mathrm{~m}$ long metal trough, respectively. The lightning period was set from 07:00 to 19:00 h. To meet animal welfare standards, (manipulable) materials were provided. Visual contact as well as nose contact to other pigs were possible the whole time.

\section{Diets and Feeding Concept}

Diets were formulated to meet or exceed nutrient requirements of three-13-week-old pigs [Gesellschaft für Ernährungsphysiologie (GfE), 2006]. Two granulated feed (control and BC-test) served as the basis for the three diets used in the trials (composition listed in Table 2). Control required no further processing and served as control diet (CON). The experimental diets (BC 1 and BC 2) contained $2 \%(\mathrm{w} / \mathrm{w})$ of biochar 1 or biochar 2 , respectively. The basis of the two experimental feeds (BCtest) was a slightly concentrated form of the control feed, so that after adding the biochar, the different diets were virtually iso-energetic (Table 3). Mixing of the biochars into the basis feed was performed by a plowshare mixer (Gebrüder Lödige Maschinenbau GmbH, Paderborn, Germany) at the Institute for Animal Nutrition, University of Veterinary Medicine Hannover, Foundation, Germany. The diet was offered ad libitum. Fresh feed was given every morning. Feed refusals were removed each morning (trial one) or at the end of each experimental week (trial two), respectively, and weighed after drying at $103^{\circ} \mathrm{C}$ so the quantity could be measured as accurately as possible. 


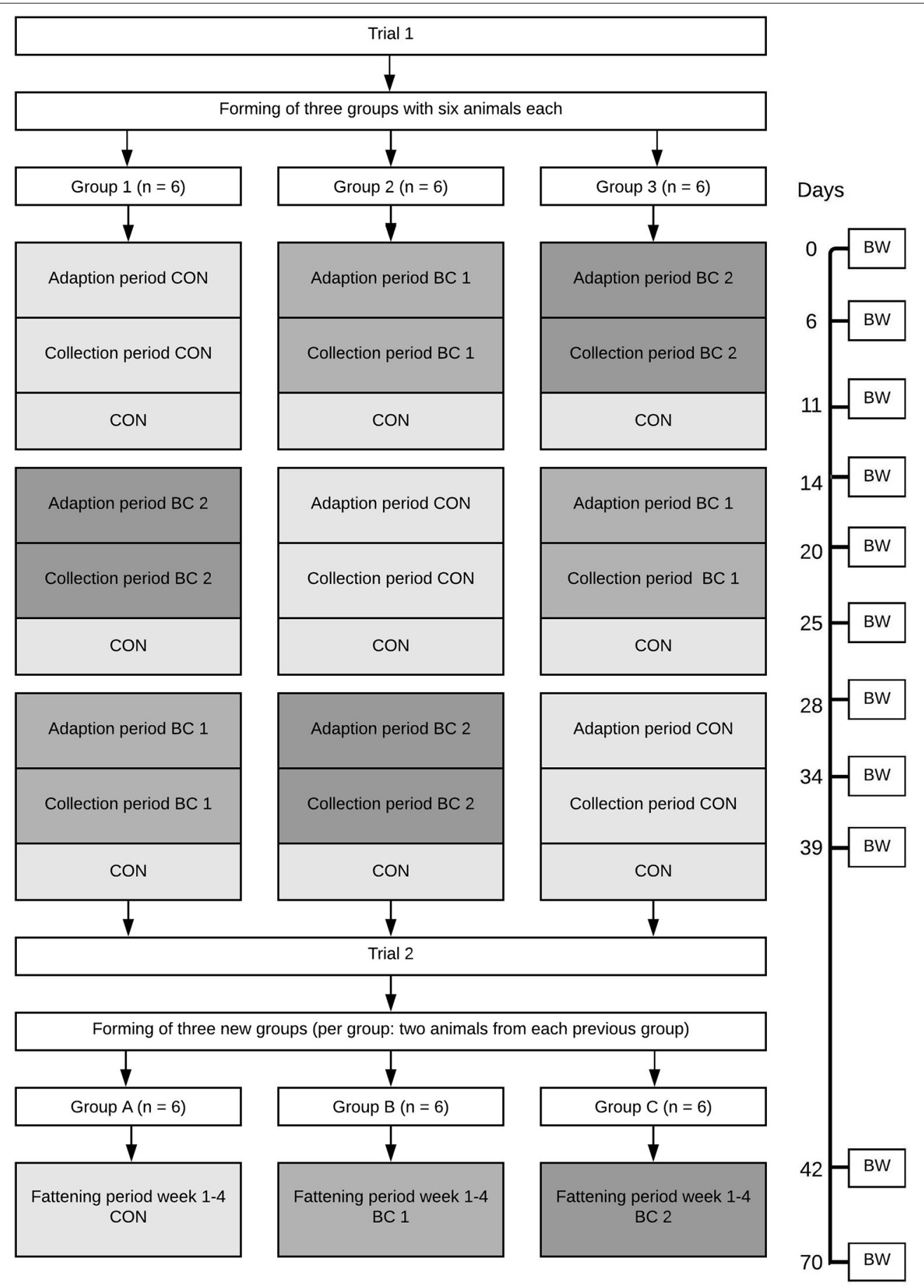

FIGURE 1 | Scheme of the test procedure. CON, control diet (no addition of biochar); BC 1, Biochar 1 (diet containing 2\% biochar 1); BC 2, Biochar 2 (diet containing $2 \%$ biochar 2); BW, Body weight $(N=18)$.

\section{Experimental Procedure}

The study was split into two trials (see Figure 1). The first trial consisted of three feeding cycles (FC 1-3), each lasting 14 days. The animals were divided into three groups (groups 1, 2, 3) according to BW and litter affiliation. By using a $3 \times 3$ Latin square-design, each group was assigned once to each diet (CON, BC 1 or BC 2, respectively) in one of the three FC for 10 days, followed by 4 days of CON for all groups in every FC. Within each FC, a digestibility study was performed modified in accordance with Schiemann (1981) and Drochner et al. (2005). The first 5 
days of feeding served as an adaption period, whereas during the following 5 days (days 6-10; days 20-24; days 34-38), feces were collected completely and individually. During the day, feces were refrigerated at $6^{\circ} \mathrm{C}$. At the end of the day, the feces were weighed for each animal before freezing at $-18^{\circ} \mathrm{C}$ until further processing. The feces that were collected over a 5-day period were pooled for each animal. After determining the dry matter content in an aliquot by oven drying, the remains of the fecal samples were freeze-dried and ground through a $0.5 \mathrm{~mm}$ sieve. The samples were analyzed for ash, CP, ether extract (EE), and crude fiber (CF) as well as for calcium, phosphorus, iron, copper, zinc, and selenium. Apparent total tract digestibility (ATTD) was calculated using the following equation:

$$
\operatorname{ATTD}_{x}=\left(\frac{x_{i}-x_{f}}{x_{i}}\right) \times 100
$$

where $\mathrm{x}$ is the variable (e.g., DM, OM or CP), $i$ stands for individual intake and $f$ for the amount excreted with the feces. To calculate ATTD, the difference between nutrient intake and its fecal excretion was divided by the amount of nutrient intake. ATTD was given in percent [\%]. BW was measured before adaption period as well as before and after the collection period and feed intake was determined daily.

By the start of trial two (T2), the 18 animals were divided into three new groups (groups A, B, C). This time, not only BW and litter affiliation were taken into account, but also that there were two animals from each previous group in each of the new groups. Every group was fed one of the three experimental feeds for the following 4 weeks. During this time, feed intake and BW were quantified weekly.

\section{Analytical Procedures}

Diets and feces were analyzed by standard procedures in accordance with the official methods of the VDLUFA (Naumann and Bassler, 2012). To determine DM, samples were dried at $103^{\circ} \mathrm{C}$ until weight constancy. Ash was analyzed by means of incineration in the muffle furnace at $600^{\circ} \mathrm{C}$ for $6 \mathrm{~h}$. To determine total nitrogen content the DUMAS combustion method (Vario $\operatorname{Max}^{\circledR}$, Elementar, Hanau, Germany) was applied. To calculate the CP content total $\mathrm{N}$ was multiplied by a constant factor of 6.25. The determination of EE contents was carried out after acid hydrolysis in the Soxhlet apparatus. The CF content was analyzed through washing the samples in dilute acids and alkalis, while an enzymatic determination (UV method, R-Biopharm AG, Darmstadt, Germany) was used to detect the content of starch. Minerals were determined by atomic absorption spectrometry after dry ashing of the samples (Unicam Solaar 116, Thermo, Dreieich, Germany).

\section{Statistical Analysis}

Analyses were performed with the statistical software SAS (SAS Institute, Cary, NC, USA), using SAS enterprise Guide 7.1. Data were tested for normal distribution. If normal distribution was given, one-way analysis of variance (ANOVA) was used for the parameters BW, average daily weight gain (AWDG), average daily feed intake (ADFI), and feed efficiency (gain-to-feed ratio,
TABLE 4 | Body weight (BW, mean \pm SD), average daily weight gain (ADWG, mean $\pm S D)^{1}$, average daily feed intake (ADFI, mean $\left.\pm S D\right)^{1}$, and feed efficiency (G:F, mean $\pm \mathrm{SD})^{1}$ during feeding cycle 1 (FC1).

\begin{tabular}{lccccc}
\hline Item & & CON $^{2}$ & BC 1 & BC 2 & p-Value \\
\hline BW d0 & $\mathrm{kg}$ & $6.95 \pm 0.88$ & $6.83 \pm 1.57$ & $6.87 \pm 1.17$ & 0.986 \\
BW d11 & & $9.58 \pm 1.20$ & $9.85 \pm 2.23$ & $9.52 \pm 1.39$ & 0.935 \\
ADWG & g/d & $239 \pm 51.3$ & $274 \pm 64.1$ & $244 \pm 47.2$ & 0.319 \\
ADFl & & $257 \pm 67.4$ & $297 \pm 65.9$ & $281 \pm 38.1$ & 0.500 \\
G:F & $\mathrm{kg} / \mathrm{kg}$ & $0.861 \pm 0.128$ & $0.734 \pm 0.102$ & $0.715 \pm 0.041$ & 0.692 \\
\hline
\end{tabular}

${ }^{1}$ Mean value over the first 10 days of FC1.

${ }^{2}$ Number of animals per treatment $n=6$.

${ }^{3}$ Feed efficiency calculated as gain per feed.

G:F). For non-normal distributed data, initially, the KruskalWallis-test was used and in case of significant differences between the groups, the Wilcoxon-test was performed for pairwise comparison between two groups. Statistical evaluation of the parameters ATTD of nutrients and DM content in feces was carried out by using two-way ANOVA. Differences were taken to be statistically significant when $p<0.05$.

\section{RESULTS}

\section{Average Daily Feed Intake, Average Daily Weight Gain, and Feed Efficiency}

Feed intake and body weight increased continuously throughout the trials in all groups, from an average of $278 \pm 57.7$ to 1997 $\pm 312 \mathrm{~g} / \mathrm{d}$ and from $6.96 \pm 1.21$ to $62.3 \pm 8.07 \mathrm{~kg}$, respectively. Tables 4-7 show mean BW, mean ADWG, mean ADFI, and mean G:F of the groups for feeding cycles 1 to 3 (FC1-3) and trial 2. BW did not differ significantly throughout the trials. Only in the fourth week of the fattening period was ADWG significantly higher for both biochar groups (group $\mathrm{B}+25.8 \%$, group $\mathrm{C}+$ $34.7 \%$ ) compared to the CON, but considered over the entire 4 weeks, the ADFI between the groups did not differ significantly (CON: $1022 \pm 233 \mathrm{~g} / \mathrm{d}$; BC 1: $1118 \pm 221 \mathrm{~g} / \mathrm{d}$; BC 2: $1118 \pm 227$ $\mathrm{g} / \mathrm{d})$. No significant differences were found in relation to ADFI either. In trial 2, the ADFI was $1676 \pm 466 \mathrm{~g} / \mathrm{d}(\mathrm{CON}), 1801 \pm$ $239 \mathrm{~g} / \mathrm{d}$ (BC 1), and $1835 \pm 160 \mathrm{~g} / \mathrm{d}$ (BC 2), respectively. The results of the G:F appeared to be inconsistent but do also not differ significantly. The G:F in trial 2 was $0.550 \pm 0.036(\mathrm{CON})$, $0.550 \pm 0.015$ (BC 1), and $0.547 \pm 0.020$ (BC 2), respectively.

\section{Apparent Total Tract Nutrient Digestibility}

The evaluation of the digestibility study revealed that ATTD of DM, OM, EE, CF, and NfE was higher in both biochar groups than in the control group. Particularly ATTD of EE (CON: $70.8^{\mathrm{b}} \%$, BC 1: $75.8^{\mathrm{a}} \%$, BC $2: 77.7^{\mathrm{a}} \% ; p<0.001$ ) and $\mathrm{CF}$ (CON: $30.8^{\mathrm{b}} \%$, BC 1: $38.4^{\mathrm{a}} \%$, BC 2: $40.4^{\mathrm{a}} \%$; $\left.p=0.004\right)$ were significantly lower in CON. ATTD of CP was higher for BC 2 compared to $\mathrm{CON}$, but in $\mathrm{BC} 1$, it was neither significant different to CON nor to BC 2 (CON: $81.0^{\mathrm{b}} \%$; BC $1: 82.4^{\mathrm{ab}} \%$; BC 2 : $\left.84.2^{\mathrm{a}} \% ; p=0.023\right)$. For the ATTD of major and minor elements, namely phosphorous, calcium, iron, copper, zinc, and selenium, 
TABLE 5 | Body weight (BW, mean \pm SD), average daily weight gain (ADWG, mean $\pm \mathrm{SD})^{1}$, average daily feed intake (ADFl, mean $\left.\pm \mathrm{SD}\right)^{1}$, and feed efficiency (G:F, mean $\pm \mathrm{SD})^{1}$ during feeding cycle 2 (FC2).

\begin{tabular}{lccccc}
\hline Item & & CON $^{2}$ & BC 1 $^{2}$ & BC $^{2}$ & $\boldsymbol{p}^{\mathbf{2}}$ \\
\hline BW d14 & $\mathrm{kg}$ & $11.2 \pm 2.32$ & $10.5 \pm 1.72$ & $10.7 \pm 1.13$ & 0.824 \\
BW d25 & & $18.2 \pm 4.04$ & $17.8 \pm 2.30$ & $17.0 \pm 2.87$ & 0.815 \\
ADWG & $\mathrm{g} / \mathrm{d}$ & $638 \pm 164$ & $661 \pm 75.1$ & $573 \pm 173$ & 0.562 \\
ADFI & & $765 \pm 208$ & $823 \pm 118$ & $693 \pm 150$ & 0.406 \\
G:F & $\mathrm{kg} / \mathrm{kg}$ & $0.758 \pm 0.062$ & $0.842 \pm 0.079$ & $0.685 \pm 0.062$ & 0.808 \\
\hline
\end{tabular}

${ }^{1}$ Mean value over the first 10 days of FC2.

${ }^{2}$ Number of animals per treatment $n=6$.

${ }^{3}$ Feed efficiency calculated as gain per feed.

TABLE 6 | Body weight (BW, mean \pm SD), average daily weight gain (ADWG, mean $\pm \mathrm{SD})^{1}$, average daily feed intake (ADFI, mean $\left.\pm \mathrm{SD}\right)^{1}$, and feed efficiency (G:F, mean $\pm \mathrm{SD})^{1}$ during feeding cycle 3 (FC3).

\begin{tabular}{|c|c|c|c|c|c|c|}
\hline Item & & & $\mathrm{CON}^{2}$ & $\mathrm{BC} 1^{2}$ & BC $2^{2}$ & $p$-Value \\
\hline BW & d 28 & $\mathrm{~kg}$ & $20.5 \pm 3.06$ & $18.7 \pm 2.87$ & $20.5 \pm 4.71$ & 0.644 \\
\hline BW & d 39 & & $29.8 \pm 3.80$ & $28.8 \pm 4.41$ & $31.6 \pm 6.90$ & 0.665 \\
\hline ADWG & & $g / d$ & $850 \pm 166$ & $918 \pm 179$ & $1006 \pm 231$ & 0.400 \\
\hline ADFI & & & $1171 \pm 208$ & $1147 \pm 204$ & $1318 \pm 298$ & 0.431 \\
\hline$G: F^{3}$ & & $\mathrm{~kg} / \mathrm{kg}$ & $0.645 \pm 0.080$ & $0.732 \pm 0.048$ & $0.801 \pm 0.128$ & 0.188 \\
\hline
\end{tabular}

${ }^{1}$ Mean value over the first 10 days of FC2.

${ }^{2}$ Number of animals per treatment $n=6$.

${ }^{3}$ Feed efficiency calculated as gain per feed.

TABLE 7 | Body weight (BW, mean \pm SD), average daily weight gain (ADWG, mean $\pm S D$ ), average daily feed intake (ADFI, mean $\pm S D$ ), and feed efficiency (G:F, mean $\pm S D$ ) during trial 2 (T2).

\begin{tabular}{|c|c|c|c|c|c|c|}
\hline Item & & & CON $^{1}$ & $\mathrm{BC} 1^{1}$ & $\mathrm{BC} 2^{1}$ & $p$-Value \\
\hline \multirow[t]{2}{*}{ BW } & $d^{2} 0$ & $\mathrm{~kg}$ & $31.6 \pm 7.18$ & $31.8 \pm 2.78$ & $32.6 \pm 5.75$ & 0.943 \\
\hline & d 28 & & $60.2 \pm 13.1$ & $62.9 \pm 3.88$ & $63.6 \pm 5.09$ & 0.761 \\
\hline ADWG & T2 mean $^{3}$ & $3 \mathrm{~g} / \mathrm{d}$ & $1022 \pm 233$ & $1118 \pm 221$ & $1118 \pm 227$ & 0.424 \\
\hline ADFI & T2 mean & & $1676 \pm 466$ & $1801 \pm 239$ & $1835 \pm 160$ & 0.576 \\
\hline $\mathrm{G}: \mathrm{F}^{4}$ & T2 mean & $\mathrm{kg} / \mathrm{kg}$ & $0.550 \pm 0.036$ & $0.550 \pm 0.015$ & $0.547 \pm 0.020$ & 0.983 \\
\hline
\end{tabular}

${ }^{1}$ Number of animals per treatment $n=6$.

${ }^{2} d$, experimental day of $\mathrm{T} 2$.

${ }^{3}$ T2 mean, mean value over the entire T2.

${ }^{4}$ Feed efficiency calculated as gain per feed.

few significant differences were found. ATTD of phosphorous and calcium was significantly higher in both biochar groups compared to $\mathrm{CON}$ ( $p<0.001$ and $p=0.017$, respectively) and ATTD of zinc and iron was higher in BC 2 in contrast to the other two feeding groups ( $p<0.001$ and $p=0.036$, respectively).

The results of the digestibility study are shown in Table 8 and Figure 2.

\section{Dry Matter Content of the Feces}

For calculating the digestibility, the DM content of the feces $\left(\mathrm{DM}_{\text {feces }}\right)$ was determined (Table 9). Results showed that $\mathrm{DM}_{\text {feces }}$
TABLE 8 | Apparent total tract digestibility (ATTD, \%) values of dry matter, organic matter, macro, and micro nutrients in piglets $(N=54)$.

\begin{tabular}{lcrrr}
\hline ATTD of & CON $^{\mathbf{1}}$ & BC $^{\mathbf{1}}$ & BC $^{\mathbf{1}}$ & \multicolumn{1}{c}{$\boldsymbol{p \text { -Value }}$} \\
\hline $\mathrm{DM}$ & $82.9^{\mathrm{b}} \pm 2.8$ & $85.7^{\mathrm{a}} \pm 2.1$ & $87.1^{\mathrm{a}} \pm 2.4$ & $<0.001$ \\
$\mathrm{OM}$ & $83.8^{\mathrm{b}} \pm 2.8$ & $86.5^{\mathrm{a}} \pm 1.9$ & $87.9^{\mathrm{a}} \pm 2.3$ & $<0.001$ \\
$\mathrm{CP}$ & $81.0^{\mathrm{b}} \pm 4.1$ & $82.4^{\mathrm{ab}} \pm 3.6$ & $84.2^{\mathrm{a}} \pm 3.4$ & 0.046 \\
$\mathrm{EE}$ & $70.8^{\mathrm{b}} \pm 3.6$ & $75.8^{\mathrm{a}} \pm 3.1$ & $77.7^{\mathrm{a}} \pm 3.1$ & $<0.001$ \\
$\mathrm{CF}$ & $30.8^{\mathrm{b}} \pm 13.4$ & $38.4^{\mathrm{a}} \pm 8.2$ & $40.4^{\mathrm{a}} \pm 12.2$ & 0.036 \\
$\mathrm{NfE}$ & $89.1^{\mathrm{c}} \pm 2.1$ & $91.5^{\mathrm{b}} \pm 1.3$ & $92.6^{\mathrm{a}} \pm 1.5$ & $<0.001$ \\
$\mathrm{P}$ & $71.6^{\mathrm{b}} \pm 3.0$ & $75.3^{\mathrm{a}} \pm 5.0$ & $77.3^{\mathrm{a}} \pm 4.3$ & $<0.001$ \\
$\mathrm{Ca}$ & $79.9^{\mathrm{a}} \pm 6.2$ & $84.1^{\mathrm{a}} \pm 6.9$ & $83.5^{\mathrm{a}} \pm 7.5$ & 0.146 \\
$\mathrm{Fe}$ & $12.6^{\mathrm{a}} \pm 7.4$ & $13.6^{\mathrm{a}} \pm 9.0$ & $19.8^{\mathrm{a}} \pm 10.6$ & 0.054 \\
$\mathrm{Cu}$ & $21.5^{\mathrm{a}} \pm 6.3$ & $16.1^{\mathrm{a}} \pm 9.2$ & $21.1^{\mathrm{a}} \pm 10.8$ & 0.141 \\
$\mathrm{Zn}$ & $14.4^{\mathrm{b}} \pm 9.3$ & $18.3^{\mathrm{b}} \pm 7.1$ & $26.0^{\mathrm{a}} \pm 11.9$ & 0.002 \\
$\mathrm{Se}$ & $68.7^{\mathrm{a}} \pm 8.0$ & $72.1^{\mathrm{a}} \pm 9.1$ & $70.1^{\mathrm{a}} \pm 13.7$ & 0.626 \\
\hline
\end{tabular}

${ }^{1}$ Number of replicates $n=18$ per treatment.

$a, b, c$ Superscripts indicate significance. Means in the same row with common superscripts are not significantly different.

differed between CON and the BC treatments (CON: $25.3^{\mathrm{b}} \%, \mathrm{BC}$ 1: $27.9^{\mathrm{a}} \%$, BC 2: $\left.29.1^{\mathrm{a}} \%\right)$.

\section{DISCUSSION}

The use of biochar in livestock farming as a feed supplement has been increased to improve animal health, increase nutrient intake efficiency and thus productivity (Schmidt et al., 2019). Few studies have reported the effect of biochar as a feed ingredient in diets for pig production (Chu et al., 2013a; Kim et al., 2017; Sivilai et al., 2018). In the present study, the effects of two different biochars (produced from beech, larch, spruce, and oak and only oak, respectively) on the performance, e.g., bodyweight gain, feed intake, and feed efficiency as well as on the nutrient digestibility in growing pigs were of particular interest. Biochars used as a feed supplement in various studies are commonly derived from wood and many other types of biomass (Schmidt et al., 2019). In order to facilitate comparability with future and existing studies, the biochars were characterized in advance regarding BET-surface area, surface energy and C-content, inter alia. Regarding surface energy the two biochars showed similar results (26.3 and 22.5 $\mathrm{mN} / \mathrm{m}$, respectively). Surface energy is a parameter describing how well a surface is wetted by liquids. Therefore, it can be assumed that the two biochars are distributed in the chyme (liquid with a high viscosity) in a similar way.

When evaluating the performance parameters, the outcome of the current study showed that ADWG, ADFI and G:F of the groups (groups 1, 2, 3 and groups A, B, C, respectively) did not differ significantly neither in trial 1 nor in trial 2. Similar results were obtained by Kupper et al. (2015), who observed no negative impact on growth performance when young pigs were fed diets containing 3\% commercial biochar for 28 days. The biochar treatment did not reveal any significant differences in daily weight gain, feed consumption, and feed conversion rate compared to the control group that received the feed without 


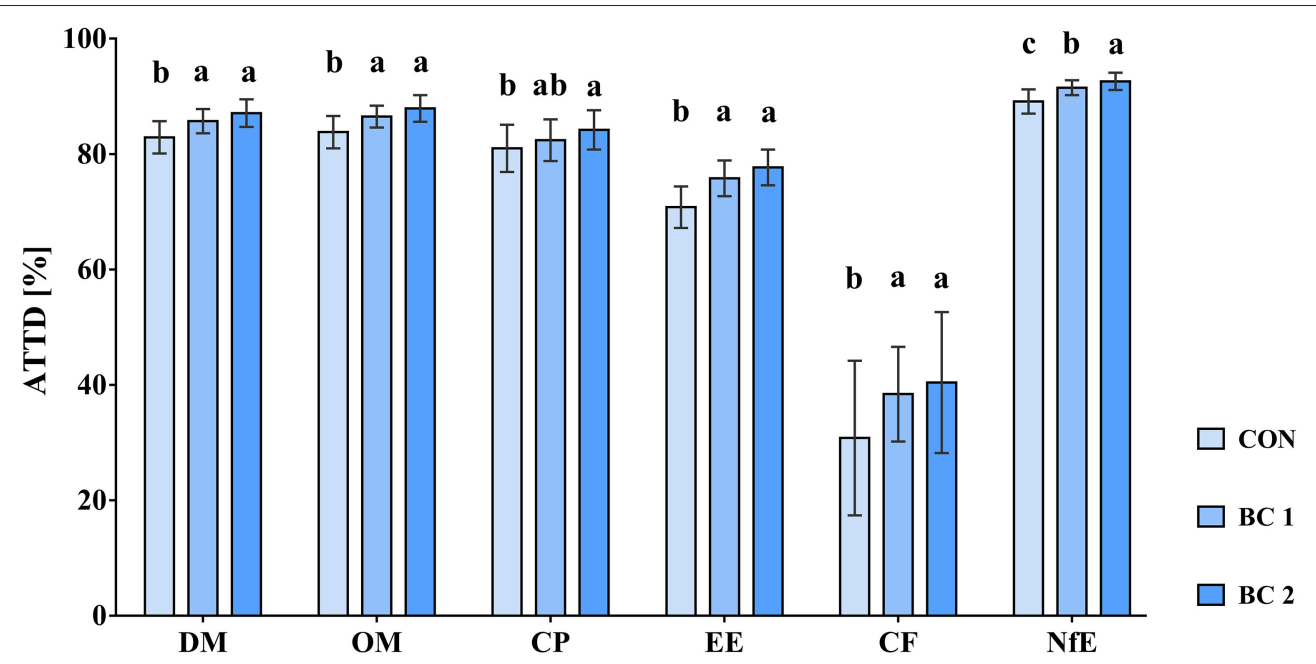

FIGURE 2 | Apparent total tract nutrient digestibility (ATTD \%) of DM, OM, and macro nutrients in growing pigs depending on the treatment ( $N=54, n=18$ ). CON, control diet (no addition of biochar); BC 1, Biochar 1 (diet containing 2\% biochar 1); BC 2, Biochar 2 (diet containing $2 \%$ biochar 2). Different letters (a, b, c) show significant differences between the treatments for each parameter $(p<0.05)$.

TABLE 9 | Dry matter content of feces $(\mathrm{g} / \mathrm{kg}$, mean \pm SD) in piglets $(N=54)$.

\begin{tabular}{lccc}
\hline & Treatment & & $p$-Value \\
\hline CON $^{1}$ & BC $\mathbf{1}^{\mathbf{1}}$ & ${\text { BC } \mathbf{~}^{\mathbf{1}}}$ & \\
\hline $253^{\mathrm{b}} \pm 25.4$ & $279^{\mathrm{a}} \pm 33.2$ & $291^{\mathrm{a}} \pm 29.6$ & $<0.001$ \\
\hline
\end{tabular}

${ }^{1}$ Number of replicates $n=18$ per treatment.

${ }^{a, b}$ Superscripts indicate significance. Means in the same row with common superscripts are not significantly different.

the biochar containing supplement. Whereas Chu et al. (2013b) showed in finishing pigs (79 kg BW to slaughter weight) an increase in daily weight gain of 14.5 and $8.20 \%$ and an improved feed efficiency of 14.9 and $11.7 \%$ when adding 0.3 and $0.6 \%$ bamboo charcoal, respectively. Not only the lower charcoal concentration but also the higher weight of the animals (79$116 \mathrm{~kg}$ ) and the use of bamboo charcoal which is said to have a different structure of micropores than wood charcoal (Chungpin et al., 2004), make a comparison between the studies difficult. The ADFI, which was not different between the groups in both trials, indicated that the two biochars did not negatively affect the palatability of the fodder. This goes in line with several studies in fattening pigs, where adding 0.3 and $0.6 \%$ charcoal to the diet had no effect on ADFI (Choi et al., 2012; Chu et al., 2013a,b). Nevertheless, contrary findings were observed by Erickson et al. (2011) who showed a decreasing acceptance of the feed with increasing concentrations of activated carbon in lactating cows.

However, the evaluation of the effects of the two biochars on the performance parameters is also complicated by the lower $\mathrm{CP}$ content of the biochar diets (CON: $19.4 \%$ DM, BC 1: $18.0 \%$ DM; BC 2: 17.7\% DM). In swine diets, not only the total protein content but also the lysine content is of particular interest, as lysine is the first limiting amino acid in pigs. The lysine requirement is expressed as lysine intake per day (National
Research Council (NRC), 2012). In the present trials, the average daily lysine intake ( $\mathrm{g} / \mathrm{d}$ ) did not differ significantly in any period between the groups, so that the different protein levels should be negligible. Effects on digestibility due to differences in the diets also have to be considered. The increased ATTD of CP in BC 2 by $3.80 \%$ compared to CON could have been caused by different CP contents, as Li et al. (1993) found an increased ileal digestibility of CP for decreasing dietary levels of CP from 25.5 to $16.5 \%$. Shi et al. (2018) confirmed this effect in terms of apparent fecal protein digestibility in a diet containing $100 \mathrm{~g} / \mathrm{kg}$ CP compared to diets containing 130 and $160 \mathrm{~g} / \mathrm{kg} \mathrm{CP}$, but found no differences between the two diets higher in protein content. This indicates that the higher ATTD of CP in this study is not attributed to different dietary protein levels. With regard to OM, EE, CF, and NfE contents, the three diets differ only marginally.

In general, the present results are in fair accordance with the existing data on nutrient digestibility in piglets. Comparing the values obtained by Slama et al. (2020), who fed a barley and soy based diet to piglets, with the results of CON for ATTD of DM ( 82.9 vs. $82.9 \%$ ), OM (85.2 vs. $83.8 \%$ ), and CP (80.5 vs. $81.0 \%)$ there are only minimal differences. Likewise, the ATTD of Ca and $\mathrm{P}$ in FC 2 (80.3 and 74.0\%, data not shown) are in perfect agreement with the results obtained by Dersjant-Li et al. (2017). In their study, piglets with an initial BW of $11 \mathrm{~kg}$ digested $77.3 \%$ of the calcium and $73.6 \%$ of the phosphorous in a wheat based diet, and $81.3 \%$ of the calcium and $75.8 \%$ of the phosphorous in a corn based diet, respectively.

To the best of our knowledge, the literature on the effects of biochar on digestibility is limited. Kim et al. (2017) showed that by using an in vitro design, that the supplementation of $0.25 \%$ organic medicinal charcoal to a pig feed improved the digestibility of DM and OM in comparison to the basal diet without charcoal by 4.9 and $3.9 \%$, respectively. In the present study, differences in the ATTD mainly existed for macronutrients but only exceptionally for minor nutrients. The increased ATTD 
of OM, CP (only in BC 2), EE, CF, and NfE also led to an increase in DM digestibility in BC 1 and BC 2 although biochar as an inert substance cannot be digested (Cooney, 1995). Despite the fact that standardized ileal digestibility (SID) of $\mathrm{CP}$, which takes into account endogenous protein losses, has a greater validity than the ATTD of CP in pig nutrition (Sauer and Ozimek, 1986), only the ATTD could be referred to due to the study design and lack of information regarding basal endogenous protein losses in diets containing biochar. However, the endogenous losses bias the digestibility especially in the case of low protein levels $(<170.7 \mathrm{~g}$ CP $/ \mathrm{kg}$ DM; Fan et al., 1994) and, additionally, poor protein quality in particular leads to differences between ileal and fecal digestibility values (Mosenthin et al., 2000).

It can be assumed that biochar effects the digestive processes in the large intestine, as it has been shown that biochar can influence the intestinal microflora (Chu et al., 2013b; Kim et al., 2017; Terry et al., 2019) and bacterial populations in general (Pietikäinen et al., 2000; Thies and Rillig, 2009; Chen et al., 2014; Kappler et al., 2014). Furthermore, a comparison between the processes in the (artificial) rumen and gastrointestinal tract of pigs is possible as the microbes in the rumen and large intestine of pigs, which are responsible for the breakdown of plant fibers, are similar (Leser et al., 2002). In the study by Saleem et al. (2018) on the effects of biocarbon on rumen fermentation in an artificial rumen (RUSTIEC), the diet was based on barley silage and treatments were $0,0.5,1$, and $2 \%$ biocarbon of substrate DM. With increasing biocarbon also the disappearance of DM, OM, CP, ADF, and NDF linearly increased. The greatest difference was found for the disappearance of ADF from 29.9 to $38.2 \%$, which is an increase of $21.7 \%$ between the control and $2 \%$ biocarbon. The ATTD of CF in this study could be improved by $23.8 \%$ due to the addition of $2 \%$ biochar 2. Chemically, the two parameters CF and NDF are similar. The first includes insoluble parts of cellulose, hemicellulose and lignin, the latter, soluble and insoluble cellulose and lignin (Paloheimo, 1969; Van Soest et al., 1991). Anyway, both describe fractions of cell wall components and cannot be degraded by endogenous enzymes but only by microbial processes (Van Soest et al., 1991).

Another effect of the biochar was noticeable in terms of $\mathrm{DM}_{\text {feces }}$ that was elevated by $9.31 \%$ (BC 1) and $13.1 \%$ (BC 2), respectively. In male fattening turkeys $0.2 \%$ dietary charcoal increased dry matter content in the litter by 6.81 percentage points (Hinz et al., 2019). Even though the underlying mechanisms are not fully understood, it seems plausible that biochar has been used successfully for centuries as a household remedy against diarrhea (Schmidt et al., 2019).

\section{REFERENCES}

Ameloot, N., Graber, E. R., Verheijen, F. G. A., and De Neve, S. (2013). Interactions between biochar stability and soil organisms: review and research needs. Eur. J. Soil Sci. 64, 379-390. doi: 10.1111/ejss.12064

Chen, S., Rotaru, A. E., Shrestha, P. M., Malvankar, N. S., Liu, F., Fan, W., et al. (2014). Promoting interspecies electron transfer with biochar. Sci. Rep. 4:5019. doi: $10.1038 /$ srep05019
Based on the results of this study and in agreement with Kim et al. (2017) and Saleem et al. (2018), it can be assumed that biochar might positively influence both enzymatic digestion in the small intestine and microbial digestion in the large intestine. Nevertheless, a higher digestibility could also be expected to result in an improved feed efficiency, which was not the case in the present study. The present investigations do not allow conclusions to be drawn concerning the exact mechanism of biochar. Therefore, more research should be conducted to study the effects of biochar on intestinal microbiota composition as well as on intestinal morphology and passage rate.

\section{DATA AVAILABILITY STATEMENT}

The original contributions generated for the study are included in the article/supplementary material, further inquiries can be directed to the corresponding author.

\section{ETHICS STATEMENT}

The animal study was reviewed and approved by Ethics committee of Lower Saxony for the Care and Use of Laboratory Animals (LAVES).

\section{AUTHOR CONTRIBUTIONS}

CV and NT: conceptualization, resources, supervision, project administration, and funding acquisition. CV, NT, DS, and FW: methodology and validation. DS and CV: formal analysis, investigation, data curation, and writing-original draft preparation. DS, FW, BC, NT, and CV: writing-review and editing. BC, DS, and CV: visualization. All authors contributed to the article and approved the submitted version.

\section{FUNDING}

This IGF project was supported via AiF within the programme for promoting the Industrial Collective Research (IGF) of the German Ministry of Economics and Energy (BMWi), based on a resolution of the German Parliament. This publication was supported by Deutsche Forschungsgemeinschaft and University of Veterinary Medicine Hannover Foundation within the funding program Open Access Publishing.

\section{ACKNOWLEDGMENTS}

We wish to thank Frances Sherwood-Brock for proof-reading the manuscript to ensure correct English.

Chia, C. H., Downie, A., and Munroe, P. (2015). "Characteristics of biochar: physical and structural properties," in Biochar for Environmental Management: Science, Technology, and Implementation, eds J. Lehmann and S. Joseph (London: Earthscan from Routledge), 89-109.

Choi, J. S., Jung, D. S., Lee, J. H., Choi, Y. I., and Lee, J. J. (2012). Growth performance, immune response, and carcass characteristics of finishing pigs by feeding stevia and charcoal. Food Sci. Anim. Resour. 32, 228-233. doi: $10.5851 /$ kosfa.2012.32.2.228 
Chu, G. M., Jung, C. K., Kim, H. Y., Ha, J. H., Kim, J. H., Jung, M. S., et al. (2013a). Effects of bamboo charcoal and bamboo vinegar as antibiotic alternatives on growth performance, immune responses, and fecal microflora population in fattening pigs. Anim. Sci. J. 84, 113-120. doi: 10.1111/j.1740-0929.2012.01045.x

Chu, G. M., Kim, J. H., Kim, H. Y., Ha, J. H., Jung, M. S., Song, Y., et al. (2013b). Effects of bamboo charcoal on the growth performance, blood characteristics, and noxious gas emission in fattening pigs. J. Appl. Anim. Res. 41, 48-55. doi: 10.1080/09712119.2012.738219

Chungpin, H., Dehjen, H., Song Yung, W., Ingluen, S., and Chunhan, K. (2004). Effect of carbonization conditions on indoor air purification of bamboo charcoal. For. Prod. Ind. 23, 183-197.

Cooney, D. O. (1995). Some Basic Aspects of Antidotal Charcoal. New York, NY: Marcel Decker Inc.

Darnhofer, I., Lamine, C., Strauss, A., and Navarrete, M. (2016). The resilience of family farms: towards a relational approach. J. Rural Stud. 44, 111-122. doi: 10.1016/j.jrurstud.2016.01.013

De Clercq, M., Vats, A., and Biel, A. (2018). “Agriculture 4.0: the future of farming technology," in Proceedings of the World Government Summit (Dubai), 11-13.

Dersjant-Li, Y., Wealleans, A. L., Barnard, L. P., and Lane, S. (2017). Effect of increasing Buttiauxella phytase dose on nutrient digestibility and performance in weaned piglets fed corn or wheat based diets. Anim. Feed Sci. Technol. 234, 101-109. doi: 10.1016/j.anifeedsci.2017.09.008

Drochner, W., Flachowsky, G., Pallauf, J., Rodehutscord, M., Shenkel, H., Staudacher, W., et al. (2005). "Determination of digestibility as the basis for energy evaluation of feedstuffs for pigs" in Proceedings of the Society of Nutrition Physiology (Frankfurt), 207-213.

EBC (2012). European Biochar Certificate-Guidelines for A Sustainable Production of Biochar. Arbaz: European Biochar Foundation (EBC). Available online at: http://www.european-biochar.org/en/download (accessed August 13, 2020).

Erickson, P. S., Whitehouse, N. L., and Dunn, M. L. (2011). Activated carbon supplementation of dairy cow diets: effects on apparent total-tract nutrient digestibility and taste preference. Prof. Anim. Sci. 27, 428-434. doi: 10.15232/S1080-7446(15)30515-5

European Commission (2013). Commission Regulation (EU) No 68/2013 of 16 January 2013 on the catalogue of feed materials. Off. J. Eur. Union 29, 1-64. doi: 10.3000/19770642.L_2013.029.deu

Fan, M. Z., Sauer, W. C., Hardin, R. T., and Lien, K. A. (1994). Determination of apparent ileal amino acid digestibility in pigs: effect of dietary amino acid level. J. Anim. Sci. 72, 2851-2859. doi: 10.2527/1994.72112851x

Fowles, M. (2007). Black carbon sequestration as an alternative to bioenergy. Biomass Bioenergy 31, 426-432. doi: 10.1016/j.biombioe.2007.01.012

Franková, E., and Cattaneo, C. (2018). Organic farming in the past and today: sociometabolic perspective on a Central European case study. Reg. Environ. Change 18, 951-963. doi: 10.1007/s10113-016-1099-8

Gesellschaft für Ernährungsphysiologie (GfE) (2006). Empfehlungen Zur EnergieUnd Nährstoffversorgung Von Schweinen. Frankfurt: DLG Verlag.

Hinz, K., Stracke, J., Schättler, J. K., Kemper, N., and Spindler, B. (2019). Effects of enriched charcoal as permanent $0.2 \%$ feed-additive in standard and lowprotein diets of male fattening turkeys: an on-farm study. Animals 9:541. doi: 10.3390/ani9080541

Isermeyer, F. (2020). Paradigm shift in livestock farming. J. Sustain. Organ. Agric. Syst. 70, 23-26. doi: 10.3220/LBF1592238146000

Kana, J. R., Teguia, A., Mungfu, B. M., and Tchoumboue, J. (2011). Growth performance and carcass characteristics of broiler chickens fed diets supplemented with graded levels of charcoal from maize cob or seed of Canarium schweinfurthii Engl. Trop. Anim. Health Prod. 43, 51-56. doi: 10.1007/s11250-010-9653-8

Kappler, A., Wuestner, M. L., Ruecker, A., Harter, J., Halama, M., and Behrens, S. (2014). Biochar as an electron shuttle between bacteria and Fe(III) minerals. Environ. Sci. Technol. Lett. 1, 339-344. doi: 10.1021/ez50 02209

Kim, K. S., Kim, Y. H., Park, J. C., Yun, W., Jang, K. I., Yoo, D. I., et al. (2017). Effect of organic medicinal charcoal supplementation in finishing pig diets. Korean J. Agric. Sci. 44, 50-59. doi: 10.7744/kjoas.20170006

Kupper, T., Fischlin, I., Häni, C., and Spring, P. (2015). "Use of a feed additive based on biochar for mitigation of ammonia emissions from weaned piglets and broilers," in RAMIRAN 2015-16th International Conference Rural-Urban Symbiosis, ed I. Körner (Hamburg: Tu Tech Verlag).
Kutlu, H. R., Ünsal, I., and Görgülü, M. (2001). Effects of providing dietary wood (oak) charcoal to broiler chicks and laying hens. Anim. Feed Sci. Technol. 90, 213-226. doi: 10.1016/S0377-8401(01)00205-X

Lehmann, J., Gaunt, J., and Rondon, M. (2006). Bio-char sequestration in terrestrial ecosystems-a review. Mitig. Adapt. Strat. Glob. Change 11, 403-427. doi: 10.1007/s11027-005-9006-5

Lehmann, J., Rillig, M. C., Thies, J., Masiello, C. A., Hockaday, W. C., and Crowley, D. (2011). Biochar effects on soil biota-a review. Soil Biol. Biochem. 43, 1812-1836. doi: 10.1016/j.soilbio.2011.04.022

Leng, R. A., Inthapanya, S., and Preston, T. R. (2013). All biochars are not equal in lowering methane production in in vitro rumen incubations. Livest. Res. Rural Dev. 25:106. Available online at: https://www.lrrd.cipav.org.co/lrrd25/6/ leng25106.htm

Leng, R. A., Preston, T. R., and Inthapanya, S. (2012). Biochar reduces enteric methane and improves growth and feed conversion in local "Yellow" cattle fed cassava root chips and fresh cassava foliage. Livest. Res. Rural Dev. 24:199. Available online at: http://www.lrrd.org/lrrd24/11/leng24199.htm

Leser, T. D., Amenuvor, J. Z., Jensen, T. K., Lindecrona, R. H., Boye, M. and Møller, K. (2002). Culture-independent analysis of gut bacteria: the pig gastrointestinal tract microbiota revisited. Appl. Environ. Microbiol. 68, 673-690. doi: 10.1128/AEM.68.2.673-690.2002

Li, S., Sauer, W. C., and Fan, M. Z. (1993). The effect of dietary crude protein level on amino acid digestibility in early-weaned pigs. J. Anim. Physiol. Anim. Nutr. 70, 26-37. doi: 10.1111/j.1439-0396.1993.tb00303.x

Majewska, T., Mikulski, D., and Siwik, T. (2009). Silica grit, charcoal, and hardwood ash in turkey nutrition. J. Elementol. 14, 489-500. doi: 10.5601/jelem.2009.14.3.07

Majewska, T., Pyrek, D., and Faruga, A. (2002). A note on the effect of charcoal supplementation on the performance of Big 6 heavy torn turkeys. J. Anim. Feed Sci. 11, 135-141. doi: 10.22358/jafs/67797/2002

Mcfarlane, Z. D., Myer, P. R., Cope, E. R., Evans, N. D., Bone, T. C., Bliss, B. E., et al. (2017). Effect of biochar type and size on in vitro rumen fermentation of orchard grass hay. Agric. Sci. 8, 316-325. doi: 10.4236/as.2017.84023

Mekbungwan, A., Yamauchi, K., and Sakaida, T. (2004). Intestinal villus histological alterations in piglets fed dietary charcoal powder including wood vinegar compound liquid. Anat. Histol. Embryol. 33, 11-16. doi: 10.1111/j.1439-0264.2004.00501.x

Mosenthin, R., Sauer, W. C., Blank, R., Huisman, J., and Fan, M. Z. (2000). The concept of digestible amino acids in diet formulation for pigs. Livest. Prod. Sci. 64, 265-280. doi: 10.1016/S0301-6226(99)00139-6

National Research Council (NRC). (2012). Nutrient Requirements of Swine, 11th revised Edn. Washington, DC: National Academy Press.

Naumann, C., and Bassler, R. (2012). Methoden der landwirtschaftlichen Forschungs-und Untersuchungsanstalt, Biochemische Untersuchung von Futtermitteln. Methodenbuch III (einschließlich der achten Ergänzungen). Darmstadt: VDLUFA.

Owens, D. K., and Wendt, R. (1969). Estimation of the surface free energy of polymers. J. Appl. Polym. Sci. 13, 1741-1747. doi: 10.1002/app.1969.070130815 Paloheimo, L. (1969). Weender analyse. Handb. Tierernahr. I 164:171.

Pereira, R. C., Muetzel, S., Arbestain, M. C., Bishop, P., Hina, K., and Hedley, M. (2014). Assessment of the influence of biochar on rumen and silage fermentation: a laboratory-scale experiment. Anim. Feed Sci. Technol. 196, 22-31. doi: 10.1016/j.anifeedsci.2014.06.019

Pietikäinen, J., Kiikkilä, O., and Fritze, H. (2000). Charcoal as a habitat for microbes and its effect on the microbial community of the underlying humus. Oikos 89, 231-242. doi: 10.1034/j.1600-0706.2000.890203.x

Renger, S., and Stachel, C. (2010). "Die Amtliche Sammlung von Untersuchungsverfahren nach $₫ \quad 64$ LFGB, $₫ \quad 35$ Vorläufiges Tabakgesetz und $₫ 28 \mathrm{~b}$ Gentechnikgesetz-ein Instrument der amtlichen Lebensmittelüberwachung," in Molekularbiologische Methoden in der Lebensmittelanalytik, ed U. Busch (Berlin: Springer), 283-295.

Ruttanavut, J., Yamauchi, K., Goto, H., and Erikawa, T. (2009). Effects of dietary bamboo charcoal powder including vinegar liquid on growth performance and histological intestinal change in Aigamo ducks. Int. J. Poult. Sci. 8, 229-236. doi: 10.3923/ijps.2009.229.236

Saleem, A. M., Ribeiro, G. O. Jr., Yang, W. Z., Ran, T., Beauchemin, K. A., Mcgeough, E. J., et al. (2018). Effect of engineered biocarbon on rumen fermentation, microbial protein synthesis, and methane production in an 
artificial rumen (RUSITEC) fed a high forage diet. J. Anim. Sci. 96, 3121-3130. doi: $10.1093 /$ jas/sky204

Sauer, W. C., and Ozimek L. (1986). Digestibility of amino acids in swine: results and their practical applications. Rev. Livest. Prod. Sci. 15, 367-388. doi: 10.1016/0301-6226(86)90076-X

Schiemann, R. (1981). Methodische Richtlinien zur Durchführung von Verdauungs-versuchen für die Futterwertschätzung. Arch. Tierernahr. 31, 1-19. doi: 10.1080/17450398109425102

Schmidt, H. P., Hagemann, N., Draper, K., and Kammann, C. (2019). The use of biochar in animal feeding. PeerJ. 7:e7373. doi: 10.7717/peerj.7373

Shi, B., Liu, J., Sun, Z., Li, T., Zhu, W., and Tang, Z. (2018). The effects of different dietary crude protein level on faecal crude protein and amino acid flow and digestibility in growing pigs. J. Appl. Anim. Res. 46, 74-80. doi: 10.1080/09712119.2016.1260570

Sivilai, B., Preston, T. R., Leng, R. A., Hang, D. T., and Linh, N. Q. (2018). Rice distillers' byproduct and biochar as additives to a forage-based diet for growing Moo Lath pigs; effects on growth and feed conversion. Livest. Res. Rural Dev. 30:111. Available online at: https://www.lrrd.cipav.org.co/lrrd30/6/ lert30111.html

Slama, J., Schedle, K., Wetscherek, W., Pekar, D., Schwarz, C., and Gierus, M. (2020). Effects of soybean hulls and lignocellulose on performance, nutrient digestibility, microbial metabolites, and immune response in piglets. Arch. Anim. Nutr. 74, 173-188. doi: 10.1080/1745039X.2019.1704174

Sun, T., Levin, B. D. A., Guzman, J. J. L., Enders, A., Muller, D. A., Angenent, L. T., et al. (2017). Rapid electron transfer by the carbon matrix in natural pyrogenic carbon. Nat. Commun. 8, 1-12. doi: 10.1038/ncomms14873

Teoh, R., Caro, E., Holman, D. B., Joseph, S., Meale, S. J., and Chaves, A. V. (2019). Effects of hardwood biochar on methane production, fermentation characteristics, and the rumen microbiota using rumen simulation. Front. Microbiol. 10:1534. doi: 10.3389/fmicb.2019.01534

Terry, S. A., Ribeiro, G. O., Gruninger, R. J., Chaves, A. V., Beauchemin, K. A., Okine, E., et al. (2019). A pine enhanced biochar does not decrease enteric CH4 emissions, but alters the rumen microbiota. Front. Vet. Sci. 6:308. doi: $10.3389 /$ fvets. 2019.00308

Thies, J. E., and Rillig, M. C. (2009). "Characteristics of biochar: biological properties," in Biochar for Environmental Management: Science and Technology, eds J. Lehmann and S. Joseph (London: Earthscan), 117-138.

Van Soest, P. J., Robertson, J. B., and Lewis, B. A. (1991). Methods for dietary fiber, neutral detergent fiber, and nonstarch polysaccharides in relation to animal nutrition. J. Dairy Sci. 74, 3583-3597. doi: 10.3168/jds.S0022-0302(91)78551-2

Van, D. T. T., Mui, N. T., and Ledin, I. (2006). Effect of method of processing foliage of Acacia mangium and inclusion of bamboo charcoal in the diet on performance of growing goats. Anim. Feed Sci. Technol. 130, 242-256. doi: 10.1016/j.anifeedsci.2006.01.008

Wang, S., Gao, B., Zimmerman, A. R., Li, Y., Ma, L., Harris, W. G., et al. (2015). Physicochemical and sorptive properties of biochars derived from woody and herbaceous biomass. Chemosphere 134, 257-262. doi: 10.1016/j.chemosphere.2015.04.062

Xie, T., Reddy, K. R., Wang, C., Yargicoglu, E., and Spokas, K. (2015). Characteristics and applications of biochar for environmental remediation: a review. Crit. Rev. Environ. Sci. Technol. 45, 939-969. doi: 10.1080/10643389.2014.924180

Conflict of Interest: The authors declare that the research was conducted in the absence of any commercial or financial relationships that could be construed as a potential conflict of interest.

Copyright (c) 2021 Schubert, Chuppava, Witte, Terjung and Visscher. This is an open-access article distributed under the terms of the Creative Commons Attribution License (CC BY). The use, distribution or reproduction in other forums is permitted, provided the original author(s) and the copyright owner(s) are credited and that the original publication in this journal is cited, in accordance with accepted academic practice. No use, distribution or reproduction is permitted which does not comply with these terms. 